\title{
The Role of Measurement in the Public Polls (Albanian Case)
}

\author{
PhD. Cand. Fatbardha DOÇI \\ Tirana University, Faculty of Social Sciences \\ fatbardhadoci@hotmail.com
}

\begin{abstract}
In Albania reality are made a lot of surveys to predict the result of elections. It is so important to have the exactly result of the election of another items to predict. A prestigious company has done the survey in Albania reality, but they have "Forgotten" that the Albania reality is different from the reality, because they have used the same questionnaires in Albania reality.It is so important to have the right measurement and to have the reliability and the validity of the survey. So we have types of measurement and in my research I have used one of them. If we used the right measurement, we can have a small margin of error and the result of the surveys should be the reliability than the other cases. I have decided to make the survey in Albanian reality lot of survey in two different realities. One of them I have used two kinds of sample, when one of them is systematic sample and another is quota sample. A comparison between two surveys is made providing the same questionnaire (with delicate questions) in the same place and time. The only difference was in the last step of the sample: one of the surveys has made the interviews based on the quota (gender, group age), whereas the other has used the systematic schema (with step - door by door). The margin decided by this way included also the one produced by the used of the quota. The expectation was a determination of differences between answers by this distinction.
\end{abstract}

Keywords: measurement, systematic sample, quota sample.

\section{Introduction}

There are a lot of concepts that are tied with each other. The concept that are tied with each other, are the types of measurement, the role of reliability, the role of validity, the role of measurement.

To have reliability and validity result we should have the good relationship with each element of the research design. Measurement provides information about where we have been, where we are currently, and whether we are changing over time. ${ }^{1}$ So it is very important to choose the right types of measurement. According to the Steven's Stately we have four types of measurement that are:

\section{Nominal Scale}

\section{Ordinal scale}

\section{Interval scale}

\section{Ratio scale}

The nominal scale simply places people, events, perceptions, etc. into categories based on some common trait. The nominal scale is the lowest form of measurement because it doesn't capture information about the focal object other than

\footnotetext{
${ }^{1}$ D. Lynn Kelley "Measurement made accessible" A Research Approach Using Qualitative, Quantitative, \& Quality Improvement Methods -SAGE Publications 200 o International Educational and Professional Publisher Thousand Oaks London New Delhi" fq 1 
whether the object belongs or doesn't belong to a category. Coding of nominal scale data can be accomplished using numbers, letters, labels, or any symbol that represents a category into which an object can either belong or not belong. ${ }^{1}$

The ordinal scale has at least one major advantage over the nominal scale. The ordinal scale contains all of the information captured in the nominal scale but it also ranks data from lowest to highest. Rather than simply categorize data by placing an object either into or not into a category, ordinal data give you some idea of where data lie in relation to each other. ${ }^{2}$

Unlike the nominal scale that simply places objects into or out of a category or the ordinal scale that rank orders objects, the interval scale indicates the distance one object is from another. In the social sciences, there is a famous example often taught to students on this distinction. ${ }^{3}$

The scale that contains the richest information about an object is ratio scaling. The ratio scale contains all of the information of the previous three levels plus it contains an absolute zero point. To use the example above, the ratio scale allows you to measure the stumps from the bottom of the lake; the bottom of the lake represents the absolute zero point. ${ }^{4}$

So I can say that I have used the ratio scale in my research in order to reduce the error margin, because it is the only types of measure that is more correctly that the other types of measurement.

\section{METHODOLOGY}

So I have done two types of survey in Tirana in different period of times, when I have used a criteria of not identify the respond and in another survey I have used another criterion when I have not identified the respondent. I emphasize that the problem that I have studied, are delicate problem and the respondent here in Albania are afraid to tell the truth. So the reliability and the validity of the result of the research it will not be the truth.

Also another element that is important in my research is the role of the sample. We have a lot of types of sample which are:

\section{i. ) Probability sampling methods.}

\section{ii) Non probability sampling methods. ${ }^{5}$}

And we can say that the belong methods of sampling are:

\section{Simple random sampling}

\section{Stratified random sampling}

\section{Cluster sampling}

\section{Quota sampling:}

\section{Purposive sampling}

\section{Systematic sampling}

\footnotetext{
1 http://www.socialresearchmethods.net/kb/measlevl.php

2 http://www.socialresearchmethods.net/kb/measlevl.php

$3 \mathrm{http}: / /$ www.socialresearchmethods.net/kb/measlevl.php

${ }^{4} \mathrm{http}: / /$ www.socialresearchmethods.net/kb/measlevl.php

${ }^{5}$ Muzammil Haque, "Sampling methods in social research", page 1 
The types of sample that I have used in my research are quota sampling and the systematic sampling, which the meanings of these are:

Quota sampling: This method of sampling is almost same with that of stratified random sampling as stated above, the only difference is that here in selecting the elements randomization is not done instead quota is taken into consideration.

Systematic sampling: In this method every $n$th element is selected from a list of population having serial number. ${ }^{1}$

I emphasize that this types of sample enter a margin of error, that effect in the reliability and the validity of the scientific research. In my study two types of these samples enter a margin of error when the systematic sampling enters an error and also the quota sampling enters an unspecified error.

\section{RESULTS OF DATA PROCESSING}

\section{Survey on the road:}

ISW $($ street $)=[\Delta$ (life satisfaction $)+\Delta$ (Happiness) $] / 2=[+4.4 \%+30.1 \%] / 2=+34.5 \% / 2=+17.25 \%$

So we have to ISW (street) $=+17.25 \%$

The survey in the family:

ISW (family) $=[\Delta$ (life satisfaction $)+\Delta$ (Happiness) $] / 2=$

$[+20 \%+28.9 \%] / 2=+48.9 \% / 2=24.45 \%$

So we have to ISW (family) $=+24.45 \%$

Margin required is:

ISW $($ family $)=+24.45 \%$ - ISW $($ street $)=+17.25 \%=+7.2 \%$

As the margin it will be $[-7.2 \%++7.2 \%]$. From this margin will be "expected" statistical error, that inserts the sample of size (for sampling with size 100 units) is $+/-10.6 \%$. We will have: $(-7.2 \%)-(-10.6 \%)=-+17.8 \%$

So the margin remains $[-17.8 \%+17.8 \%]$.

\section{CONCLUSIONS}

As conclusion, we can say it is so important to choose the right types of measurement, the right types of sampling and the right way to do the reliability results. As I have chosen the right items also results that have entered an error. This error effect negatively in the results of the surveys.

So it is so important to use the right instrument to have good results and the reliability and validity results.

\section{REFERENCES}

- Feraj H., (2004) Hyrje në shkenca politike:Tiranë, Pegi.

${ }^{1}$ Muzammil Haque, "Sampling methods in social research", page 5 
- Feraj H., Kocani A., (2013) Anonymous or Confidentiality in Opinion Survey?(The Selective Aproach for Sampling in Surveys where are Included Delicate Questions), Mediterranean Journal of Social Sciences, Vol 4 No 2, May 2013, ISSN 2039-9340.

- Kocani A., (2006) Metodat e kërkimit sociologjik: Tiranë, UFO.

- Kocani A., (2010) Një qasje metodologjike: gabimi në matje në anketim kur nuk merret në konsideratë ndryshimi i mjedisit socio-politik (rasti i sondazheve Zogby në Shqipëri), AKTET Revistë shkencore e Institutit Alb-Shkenca, Vëll. III, Nr. 4, ISSN 2073-2244.

- Kocani A., (2011) Përcaktimi i marzhit të gabimit që fut kuota në hallkën e fundit të kampionimit të një anketimi kundrejt kampionimit sistematik, AKTET Revistë shkencore e Institutit Alb-Shkenca, Vëll. IV, Nr. 4, ISSN 2073-2244.

- Popper K. R., (1982) La logique de la découverte scientifique, Payot, Paris.

-Bollen, K. A. (1989). Structural Equations with Latent Variables (pp. 179-225). John Wiley \& Sons, Dansereau, F., Alutto, J. A. and Yammarino, F. J. (1984). Theory testing in organizational behavior: The variant approach. Englewood cliffs, NJ: Prentice Hall.

-Eisner, E. W. (1991). The enlightened eye: Qualitative inquiry and the enhancement of educational practice. New York, NY: Macmillan Publishing Company.

-Healy, M., \& Perry, C. (2000). Comprehensive criteria to judge validity and reliability of qualitative research within the realism paradigm. Qualitative Market Research, 3(3), 118-126.

-Hipps, J. A. (1993). Trustworthiness and authenticity: Alternate ways to judge authentic assessments. Paper presented at the annual meeting of the American Educational Research Association. Atlanta, GA.

-Patton, M. Q. (2002). Qualitative evaluation and research methods (3rd ed. ). Thousand Oaks, CA: Sage

Publications, Inc.

-Seale, C. (1999). Quality in qualitative research. Qualitative Inquiry, 5(4), 465-478.

-Strauss, A., \& Corbin, J. (1990). Basics of qualitative research: Grounded theory procedures and techniques. Newbury Park, CA: Sage Publications, Inc. 